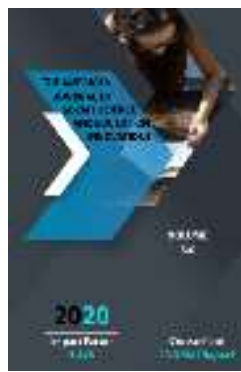

\title{
On The Study Of The Meaning Of "Ability" Within Motion Manner Category In Uzbek Language
}

\author{
Mengliyeva M.B.
}

Independent Scientific Researcher, Andijan State University, Uzbekistan

Journal Website:

http://usajournalshub.c om/index,php/tajssei

Copyright: Original content from this work may be used under the terms of the creative commons attributes 4.0 licence.

\section{ABSTRACT}

The intermediate grammatical meaning of "ability" is smaller than the number of specific meanings in "process" and is limited to "ability" and "trial". While these meanings are expressed in the phonetic layer by the extension and contraction of the sound, in the morphological layer they are expressed by the use of auxiliary verbs. These particular grammatical meanings are not represented by tense forms in the morphological layer. The meanings of "process" are expressed in the syntactic layer by word combinations with the presence of the action verb, that is, together with the verb, such words as "hardly", "with huge efforts" are combined with the word denoting the action. In the lexical layer, it can be expressed directly by verbs such as to act, to succeed. Although the intermediate meaning group "ability" is smaller in structure than the "process" group, its means are stylistically neutral and can be used in both formal and informal speech..

\section{KEYWORDS}

Motion manner, meaning of ability, meaning of trial, stylistically neutral, meaning of process, auxiliary verbs, word combinations, verbs, action.

\section{INTRODUCTION}

The second group of motion manner expressions serves to mean "ability," and this

group is smaller than the first "processivity" layer. Because there are only two categories in 
this meaning group. If "ability" is an intermediate grammatical meaning, then this meaning is divided into two specific groups: "ability" and "trial." Furthermore, while the meaning of "ability" is categorized into physical-mental activity and mental activity, there is no sub-classification in the group of "trial". It should be noted that "as the general grammatical meaning is introduced into the speech, the more it is poured into it, the more it is influenced by other phenomena - different language levels."[3:212]However, based on the table below, it can be said that the general grammatical meaning here is not so condensed, which means that the influence of different language layers is not clear and definite enough.

\begin{tabular}{|c|c|c|c|c|c|c|c|c|c|c|c|c|c|}
\hline \multicolumn{13}{|c|}{ Ability } & \\
\hline \multicolumn{7}{|c|}{ Capability } & \multirow{2}{*}{\multicolumn{7}{|c|}{ Trial }} \\
\hline \multicolumn{4}{|c|}{$\begin{array}{c}\text { physical-mental } \\
\text { activity }\end{array}$} & \multicolumn{3}{|c|}{$\begin{array}{l}\text { mental } \\
\text { activity }\end{array}$} & & & & & & & \\
\hline 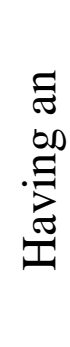 & 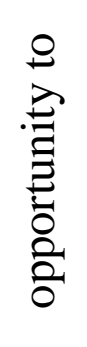 & 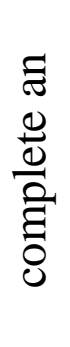 & 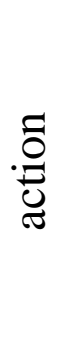 & 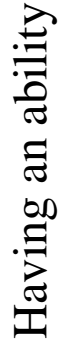 & $\begin{array}{l}\tilde{\Xi} \\
\stackrel{0}{0} \\
\frac{0}{2} \\
\overparen{\Xi} \\
0 \\
0 \\
0\end{array}$ & 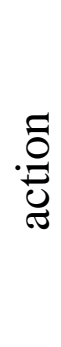 & 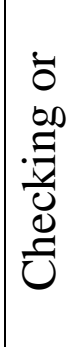 & 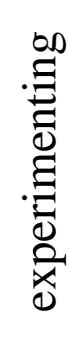 & 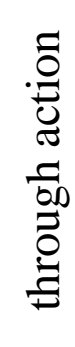 & & 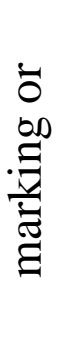 & 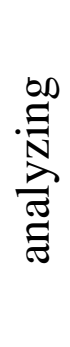 & 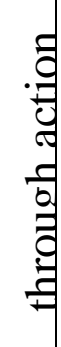 \\
\hline
\end{tabular}

At this point, it is necessary to clarify the confusing concepts of opportunity and ability before dwelling on the meanings of having the ability to perform an action and the opportunity to perform an action. "Opportunity is a budding reality, a reality that has not yet emerged. Opportunity consists of objective and subjective conditions of development that give rise to reality. Opportunity is an event that has not yet materialized, but can occur, that can become a reality. The realization of opportunity means the process of development."[2] It is clear from this that the means of style representing opportunity represent the moment when action has not yet taken place. For example, if the combinationy̆қий олади(can read) means the opportunity of beginning an action, the combination ўқий(б) олди(could read)with suffix (b) means that the action has taken place.

Thus, when the means of opportunity are combined with the forms of the past and the present, the meaning of "process" automatically takes on a special grammatical meaning, because in this case the forms of time are not only expressive of manner but also a subtle but firm boundary between the two meanings. Now let's talk about the meaning of "having the ability to perform an action." First of all, "abilities are the degree to which a particular person meets the requirements of a particular activity, the 
structure of a particular person and the structure of the requirements for a particular type of activity, the degree to which certain

As for the connection with mental activity, in V. Dahl's explanatory dictionary the word "capable" is explained as follows: "capable" is defined as "fit for something or inclined, dexterous, handy, handy, fit, co-operative, comfortable. A capable person - mentally gifted or developed; capable of mathematics, painting - inclined to this, and teachable to it."[1]

\section{MATERIALS AND METHODS}

It should be noted that the units denoting "the ability to perform an action", like expressions of opportunity, mean only ability personal characteristics are compensated by others."[4:135]

without the addition of past and present tenses. If these suffixes are added to the means, the units will automatically begin to express one of the specific grammatical meanings in the "process" layer.

The second special grammatical meaning of "ability" is divided into two layers: "try", "test, test or test the action" and "know, define, determine the action". Units such as read, think, and taste, unlike units in the "ability" category, can mean the same test even if past and present tenses are added.

In the following, we will look at the units that make up the intermediate grammatical meaning of "ability".

\begin{tabular}{|c|c|c|c|}
\hline \multicolumn{4}{|c|}{ Ability } \\
\hline \multicolumn{4}{|c|}{$\begin{array}{l}\text { Mentalandphysicalability-to have an opportunity or ability to } \\
\text { perform an action }\end{array}$} \\
\hline Phonetic layer & $\begin{array}{l}\text { Morphologic } \\
\text { layer }\end{array}$ & Syntax layer & Lexical layer \\
\hline $\begin{array}{l}\text { Strengthening } \\
\text { on auxiliary vess } \\
\text { within verb+suffix+ } \\
\text { auxiliary verb } \\
\text { combination }\end{array}$ & $\begin{array}{l}\text {-а।й+oл, - } \\
\text { alй+бил } \\
\text { ўқий олди } \\
\text { ўқий билди } \\
\text { кўра олди } \\
\text { кўзлай олди }\end{array}$ & $\begin{array}{l}\text { амаллаб } \\
\text { аранг } \\
\text { базўр } \\
\text { бамайлихотир }\end{array}$ & $\begin{array}{c}\text { амалламоқ, } \\
\text { уддаламоқ, } \\
\text { эпламоқ, } \\
\text { қўлдан келмоқ }\end{array}$ \\
\hline
\end{tabular}

"It is impossible to strictly regulate all forms of motion manner according to the degree of loss of lexical meaning. Because most of them are plural, some of the meanings they mean are linked to independent meanings, while some are not related at all. This can be seen in the example of the verb ol (to take)."[6:29] 
Furthermore, we can see that the auxiliary ol(to take)is added to the base of the main verb. In general, this auxiliary is often combined with the verb stem, but it can also group. If the form is in the form of a verb + (i) $b+o l$, in speech it signifies the completion of an action, or self-centered (e.g., saw, wrote, heard), the verb $+(a)+$ ol signifies the ability to perform an action (e.g. : saw, wrote, heard). At the same time, it is clear that the reason why the ol auxiliary, which can be considered semantically polysemantic, is functional in both groups of meanings is not that it acquires different meanings when combined with different verbs, that is, the essence of the problem is If the verb is connected with the form -ib, it represents one of the meanings of the process, when it is combined with the form -a, it begins to mean ability, and the form of direct relation plays a fundamental role in expressing the subtleties of this meaning.

Lexemes such as arang, amallab(hardly, with huge efforts) mean that an action has taken place and at the same time a lot of effort has express the meaning of the process of focusing and ending the action, as well as the specific grammatical meaning of ability in the ability intermediate grammatical meaning

been expended to perform that action, i.e. the action has been accomplished. For this reason, the lexemes can also be included in the list of units denoting the meaning of ability and continuity as well. The opposite meaning of these units is understood through such units as rhythm, success, calmness, solitude, ease, and it expresses the subtleties of meaning, such as complete ability to perform the action, no extra effort from the performer of the action.

The second special grammatical meaning test, which is part of the intermediate grammatical meaning of competence, includes various means of expression that express meanings such as verifying or experimenting with an action, as well as knowing, defining, and identifying an action. 


\begin{tabular}{|c|c|c|c|}
\hline \multicolumn{4}{|c|}{ Capability } \\
\hline \multicolumn{4}{|c|}{$\begin{array}{c}\text { Trial -checking, experimenting through action; getting to know, } \\
\text { marking or analyzing through action }\end{array}$} \\
\hline Phonetic layer & $\begin{array}{l}\text { Morphologic } \\
\text { layer }\end{array}$ & Syntax layer & Lexical layer \\
\hline $\begin{array}{l}\text { Strengthening stress } \\
\text { on auxiliary verb } \\
\text { within verb+suffix+ } \\
\text { auxiliary verb } \\
\text { combination }\end{array}$ & $\begin{array}{l}\text { й, -(и)б+кўр } \\
-(\text { и)б+боқ }\end{array}$ & $\begin{array}{l}\text { Синчиклаб, } \\
\text { бирма-бир, } \\
\text { чертиб- } \\
\text { чертиб }\end{array}$ & $\begin{array}{l}\text { синамоқ, } \\
\text { текширмоқ, } \\
\text { аниқламоқ, } \\
\text { аниқлик киритмоқ, } \\
\text { тажрибадан } \\
\text { ўтказмоқ, } \\
\text { кузатмоқ, } \\
\text { сараламоқ }\end{array}$ \\
\hline
\end{tabular}

Ko'r (to see) as well as the bo'l (to be) helpers in the table, unlike the ol (to take) helper, do not occur among the specific grammatical semantic expressions of process, and therefore we can say that these two tools serve only to express the ability meaning in their auxilary function.

\section{RESULT AND DISCUSSION}

Of course, testing means, such as sichiklab (thoroughly), birma-bir (one by one) or tekshirmoq (sorting), baholamoq (evaluating), and aniqlamoq (identifying) an action, as well as to a certain extent the process of action, or more precisely the duration of action. However, in these tools, the feature of expressing the meanings of the first group prevails, and therefore we consider it reasonable to classify them as means of expressing the meaning of the trial.

It is noteworthy that, just like the means of process, the units of ability expression serve to express and reinforce a holistic meaning in 
interaction. For example, combinations in speech, such as careful examination, one-onone experimentation, and click-through sorting, clearly demonstrate the cooperation of such different layer means.

In addition, in some cases we may witness the repetition of an element contained in a means of expression, or a combination of tarx expressions. "Strengthening the meaning of manner through the repeated use of the leading part in the form of movement is a peculiar ethnic feature of Kipchak dialects and is used relatively actively in speech."'[5:15] "The partial or complete repetition of forms of action is not only the manner of action in which it is performed, but its relation to the character or to objective reality in general, if used in the author's speech; if the character is used in speech, it also serves to express a negative or positive attitude of the other person in the discursive process to the objective reality."[5:16]It follows that the repetition of style means of expression is often used for the purpose of creating artistic description, and is in itself an element peculiar only to artistic-descriptive texts.

\section{CONCLUSION}

The units within the specific grammatical meaning mentioned above are much smaller in number and quantity than the means in the "process" layer. However, the difference between the two meaning groups is not limited to the number of units. Another difference between groups of meanings depends on the scope and context in which the means of expression are used. We know that forms of movement are characterized by different adaptations in different contexts of speech. The communication situation that provides specificity in their application can be divided into two groups:
1) Formal communication conditions;

2) Informal communication conditions.

It has been found that the auxiliary verbs stand, throw, give, put, stay, go, go out, pass, take, come, which constitute the forms of motion manner, are more adapted to the formal speech situation. This is determined by the breadth of their semantic coverage and the weakness of the semantic scope. However, a number of units that represent the meanings of ability and test are distinguished by having a specific semantic coloring. [5:50] For this reason, syntactic layer means of expression, such asarang, bazo'r(hardly, with huge efforts)and lexical manner means of expression such as eplamoq, amalmaq, uddalamoq (to be capable of) are far from methodological neutrality and cannot be used in the context of a formal, scientific text. The scope of such tools is limited to the scope of the literary text.

\section{REFERENCES}

1. https://studopedia.su/13_132384_psiho motornaya-odarennost-i-

kreativnost.html

2. https://uz.wikipedia.org/wiki/Imkoniya t_va_voqelik

3. Mengliev B.R. Interlayer relations in the integrity of the linguistic system: PhD. ... dis. - T., 2002.

4. Platonov K.K. "On the system of psychology", - M., "Thoughts", 1972.

5. Rahmatullaeva

Sh.Z.

Linguoculturological and sociopragmatic features of movement 
The American Journal of Social Science and Education Innovations (ISSN - 2689-100x)

Published: September 26, 2020 | Pages: 297-303

Doi: https://doi.org/10.37547/tajssei/Volume02Issue09-46

patterns. - abstract of the dissertation of Doctor of Philosophy (PhD). 15 b. Karshi - 2018. (50 p.)

6. Shukurov O. Paradigm of forms of movement. 29 p.- Karshi: Nasaf, 2017. 